\title{
A 10-year Follow-up Study of a Japanese Family with Ferroportin Disease A: Mild Iron Overload with Mild Hyperferritinemia Co-occurring with Hyperhepcidinemia May Be Benign
}

\author{
Hisao Hayashi ${ }^{1}$, Motoyoshi Yano ${ }^{2}$, Naohito Urawa ${ }^{3}$, Akane Mizutani ${ }^{4}$, Shima Hamaoka ${ }^{3}$, \\ Jun Araki $^{3}$, Yuji Kojima ${ }^{3}$, Yutaka Naito ${ }^{4}$, Ayako Kato ${ }^{1}$, Yasuaki Tatsumi ${ }^{1}$ and Koichi Kato ${ }^{1}$
}

\begin{abstract}
:
This is a 10-year follow-up study of a family with ferroportin disease A. The proband, a 59-year-old man showed no noteworthy findings with the exception of an abnormal iron level. The proband's 90-year-old father showed reduced abilities in gait and cognition; however, with the exception of his iron level, his biochemistry results were almost normal. Brain imaging showed age-matched atrophy and iron deposition. In both patients, the serum levels of ferritin and hepcidin25, and liver computed tomography scores declined over a 10-year period. These changes were mainly due to a habitual change to a low-iron diet. The iron disorder in this family was not associated with major organ damage.
\end{abstract}

Key words: ferroportin, iron overload, reticuloendothelial system

(Intern Med 57: 2865-2871, 2018)

(DOI: 10.2169/internalmedicine.0481-17)

\section{Introduction}

The genetic backgrounds and molecular bases of iron overload syndromes, including hereditary hemochromatosis $(\mathrm{HH})$, have been clarified over the last 2 decades (1-3). Ferroportin disease (FPD) is a new entity characterized by the iron-induced activation of the reticuloendothelial (RE) system with autosomal dominant inheritance $(4,5)$. The identification of the iron regulator, hepcidin, which is synthesized in the liver, led to a novel concept of iron homeostasis under healthy and diseased conditions (6). A subsequent study indicated that the iron exporter ferroportin (FPN) in the RE cells and enterocytes is a receptor for hepcidin, which regulates iron homeostasis by the internalization of the hepcidinFPN complex (7). FPD differs from HH-in which false signals of iron deficiency suppress hepcidin synthesis in the liver-in that FPD patients have the potential to secrete an appropriate amount of hepcidin 25 . The altered FPN molecules may therefore resist hepcidin to various degrees due to their vessel-side expression (8). Based on the impaired hepcidin/ FPN system, FPD is classified as post-hepatic iron overload (9).

There are two phenotypes of FPD, which are associated with mild and severe iron overload: FPD A occurs due to a loss-of-function mutation of SCLAOAl, while FPD B occurs due to a gain-of-function mutation; both occur worldwide $(10,11)$. The first Japanese case of FPD B involved a 43-year-old woman who showed chronic hepatitis with severe compound iron overload in her hepatocytes and Kupffer cells (12). She was heterozygous for A117G in the SLC40A1 gene, and was affected by diabetes mellitus (DM) and general pigmentation. The second case of FPD B involved a 66-year-old man with DM and severe iron overload (serum ferritin $>7,000 \mathrm{ng} / \mathrm{mL}$ ) (13). A liver biopsy specimen revealed peri-portal fibrosis associated with heavy iron overload in both parenchymal and Kupffer cells. A novel heterozygous mutation, D157G [470A $>$ C/wild type (wt)], was found in the SCLAOAl gene. None of the patient's relatives were affected by DM or chronic liver disease.

\footnotetext{
${ }^{1}$ Department of Medicine, Aichi-Gakuin University School of Pharmacy, Japan, ${ }^{2}$ Department of Gastroenterology, Yokkaichi Municipal Hospital, Japan, ${ }^{3}$ Department of Hepatology, Ise Red Cross Hospital, Japan and ${ }^{4}$ Department of Neurology, Ise Red Cross Hospital, Japan Received: November 6, 2017; Accepted: February 22, 2018; Advance Publication by J-STAGE: May 18, 2018 Correspondence to Dr. Hisao Hayashi, hhayashi@dpc.agu.ac.jp
} 
Table 1. Laboratory Data of the Case 1 with Ferroportin Disease A in the Family.

\begin{tabular}{|c|c|c|c|c|c|}
\hline \multicolumn{2}{|c|}{ Urinalysis } & \multicolumn{2}{|c|}{ Liver function } & \multicolumn{2}{|l|}{ Metabolics } \\
\hline $\begin{array}{l}\text { Protein } \\
\text { (negative) }\end{array}$ & negative & $\begin{array}{l}\text { Albumin } \\
(3.9-4.9 \mathrm{~g} / \mathrm{dL})\end{array}$ & 5.0 & $\begin{array}{l}\text { BMI } \\
(20.0-24.0)\end{array}$ & 20.5 \\
\hline $\begin{array}{l}\text { Glucose } \\
\text { (negative) }\end{array}$ & negative & $\begin{array}{l}\text { ALT } \\
(4-44 \mathrm{IU})\end{array}$ & 17 & $\begin{array}{l}\text { Fasting blood glucose } \\
(<110 \mathrm{mg} / \mathrm{dL})\end{array}$ & 97 \\
\hline \multirow[t]{3}{*}{$\begin{array}{l}\text { Urobilinogen } \\
(+/- \text { or }+)\end{array}$} & $+/-$ & $\begin{array}{l}\text { t- Bilirubin } \\
(<1.2 \mathrm{mg} / \mathrm{dL})\end{array}$ & 1.0 & $\begin{array}{l}\text { HbA1C } \\
(4.6-6.5 \%)\end{array}$ & 5.0 \\
\hline & & $\begin{array}{l}\text { ALP } \\
(104-338 \mathrm{IU} / \mathrm{L})\end{array}$ & 127 & $\begin{array}{l}\text { TG } \\
(45-149 \mathrm{mg} / \mathrm{dL})\end{array}$ & 95 \\
\hline & & $\begin{array}{l}\text { PT } \\
(70-130 \%)\end{array}$ & 95 & $\begin{array}{l}\text { LDL-C } \\
(78-148 \mathrm{mg} / \mathrm{dL})\end{array}$ & 86 \\
\hline \multicolumn{2}{|l|}{$\mathrm{CBC}$} & \multicolumn{2}{|c|}{ Renal function } & \multicolumn{2}{|l|}{ Iron parameters } \\
\hline $\begin{array}{l}\text { WBC } \\
\left(3.8-9.0 \times 10^{3} / \mu \mathrm{L}\right)\end{array}$ & 4.5 & $\begin{array}{l}\text { BUN } \\
(8.0-20.0 \mathrm{mg} / \mathrm{dL})\end{array}$ & 13.3 & $\begin{array}{l}\mathrm{Fe} \\
(44-192 \mu \mathrm{g} / \mathrm{dL})\end{array}$ & 153 \\
\hline $\begin{array}{l}\text { RBC } \\
\left(4.40-5.40 \times 10^{6} / \mu \mathrm{L}\right)\end{array}$ & 3.78 & $\begin{array}{l}\text { Creatinine } \\
(0.60-1.10 \mathrm{mg} / \mathrm{dL})\end{array}$ & 0.74 & $\begin{array}{l}\text { TF-saturation } \\
(40-70 \%)\end{array}$ & 43.5 \\
\hline $\begin{array}{l}\mathrm{Hb} \\
(13.5-17.0 \mathrm{~g} / \mathrm{dL})\end{array}$ & 13.4 & $\begin{array}{l}\text { UA } \\
(4.0-7.0 \mathrm{mg} / \mathrm{dL})\end{array}$ & 4.1 & $\begin{array}{l}\text { Ferritin } \\
(15.0-160 \mathrm{ng} / \mathrm{mL})\end{array}$ & 479 \\
\hline $\begin{array}{l}\mathrm{Ht} \\
(40-50 \%)\end{array}$ & 39.8 & $\begin{array}{l}\mathrm{Na} \\
(135-147 \mathrm{mEq} / \mathrm{L})\end{array}$ & 140 & $\begin{array}{l}\text { Hepcidin } 25 \\
(7.8+/-7.0 \mathrm{ng} / \mathrm{mL})\end{array}$ & 37.5 \\
\hline \multirow[t]{2}{*}{$\begin{array}{l}\text { Platelets } \\
\left(150-400 \times 10^{3} / \mu \mathrm{L}\right)\end{array}$} & 230 & $\begin{array}{l}\mathrm{K} \\
(3.3-4.8 \mathrm{mEq} / \mathrm{L})\end{array}$ & 3.8 & & \\
\hline & & $\begin{array}{l}\mathrm{Cl} \\
(98-108 \mathrm{mEq} / \mathrm{L})\end{array}$ & 104 & & \\
\hline
\end{tabular}

Data are presented in order to the test (upper line), normal range (left lower line in parenthesis), and result (right lower line).

Abnormal values are presented in bold numerals.

ALP: alkaline phosphatase, ALT: alanine aminotransferase, BMI: body mass index, BUN: blood urea nitrogen, CBC: complete blood count, Hb: hemoglobin, Ht: hematocrit, LDL-C: low density lipoprotein-cholesterol, PT: prothrombin time, RBC: red blood cell, t-Bilirubin: total-Bilirubin, TF: transferrin, TG: triglyceride, UA: uric acid, WBC: white blood cell

Mild hyperferritinemia and hyperhepcidinemia were associated with mild anemia in the 59-year-old proband male member of the family. He also had hyperalbunimeia due to an unknown cause.

FPD A was first found in a Japanese family in which two members, a male proband and his father, were affected by mild hyperferritinemia, but free from iron-induced organ damage (14). They were heterozygous for a novel missense mutation, R489S $(1,467 \mathrm{~A}>\mathrm{C} / \mathrm{wt})$, in the SLC40Al gene. There were no mutations in genes associated with $\mathrm{HH}$. Five years later, we reported a close relationship between their serum levels of ferritin and hepcidin25 using a new method for determining the circulating hepcidin levels $(15,16)$. This is the third report of the Japanese family with FPD A of mild iron overload in the RE system and hyperferritinemia co-occurring with hyperhepcidinemia. The elucidation of the changes in iron parameters, including circulating hepcidin 25 , and iron-induced organ damage that occurred over the decade after the diagnosis of iron disease may facilitate a better understanding of the complex issues of iron cytotoxicity.

\section{Ethical considerations}

The protocol of this 10-year follow-up study, including the hepcidin 25 determination, was approved by the ethics committees of Aichi-Gakuin University School of Pharmacy and its affiliated hospitals (AGU SP No. 62). Blood sampling was performed after obtaining informed consent from each patient.

\section{Case Reports}

\section{Case 1}

The proband, a 59-year-old man received his 3rd medical checkup for FPD A with R489S $(1,467 \mathrm{~A}>\mathrm{C} / \mathrm{wt})$ in the SLC40A1 gene, which had been diagnosed when he was 43 years of age (14). He was a retired paramedic of a general hospital. His past history included mild anemia resistant to iron removal. He was intolerant to blood donation and phlebotomy due to the poor improvement of his post-blood removal anemia. A new oral iron chelator, deferasirox, had been discontinued within a week because of severe gastrointestinal problems (17). A bed-side examination revealed that he was free from any signs of hemochromatosis, including pigmentation. There was no abnormality of the cardiovascular system. Blood tests showed mild anemia, hyperferritinemia, and hyperhepcidinemia; other test results indicated almost normal function of the patient's liver, kidneys, and endocrine system (Table 1). Findings on abdominal magnetic resonance imaging (MRI), computed tomography (CT), and 
echography were mostly normal, although the liver and spleen showed a slightly high density on CT (Fig. 1), indicating mild iron overload in the RE system. His score on

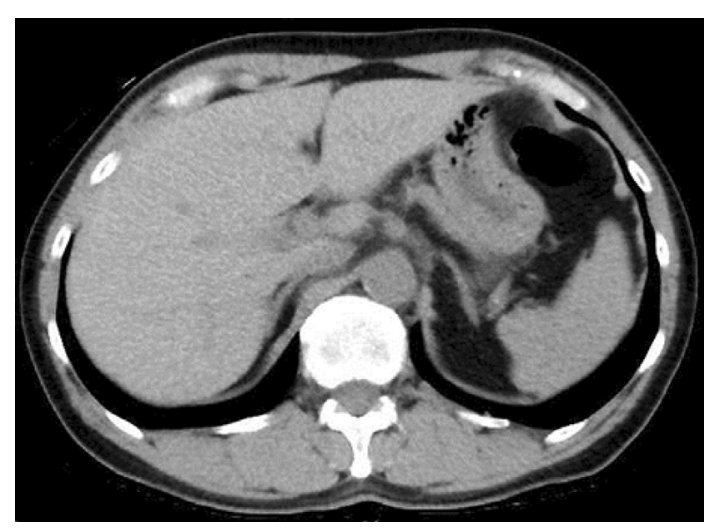

Figure 1. Abdominal CT of the 59-year-old male proband. The CT values of the liver and spleen are mildly elevated, suggesting iron overload in the RE system; the other findings are normal. the revised Hasegawa's dementia scale (HDS-R) was 30 out of 30 points.

\section{Case 2}

The proband's father, a 90-year-old man, received a follow-up medical check for FPD A (14). A few years prior to this, he had moved from his house to a nursing home, where he was able to walk from his private room to the dining room using handrails. A bed-side examination detected mild hearing loss and poor articulation, and revealed mild motor weakness of the four extremities without muscular rigidity. Cognitive impairment was diagnosed based on an HDS-R scale of 10 out of 30 points.

His body mass index was 23.0 and a urinalysis was negative for glucose. His blood pressure was $140 / 64 \mathrm{mmHg}$, and his pulse was 60 beats/min with a regular sinus rhythm. Electrocardiography (ECG) showed low-voltage $\mathrm{T}$ waves in V4 and V5 with otherwise normal limits. Mild anemia was associated with moderately increased levels of serum ferritin and hepcidin25 (Table 2). With regard to metabolic parameters, the patient's $\mathrm{HbA} 1 \mathrm{C}$ and triglyceride levels were

Table 2. Laboratory Data of the Case 2 with Ferroportin Disease A in the Family.

\begin{tabular}{|c|c|c|c|c|c|}
\hline \multicolumn{2}{|l|}{ Urinalysis } & \multicolumn{2}{|c|}{ Liver function } & \multicolumn{2}{|l|}{ Metabolics } \\
\hline $\begin{array}{l}\text { Protein } \\
\text { (negative) }\end{array}$ & negative & $\begin{array}{l}\text { Albumin } \\
(3.9-4.9 \mathrm{~g} / \mathrm{dL})\end{array}$ & 4.3 & $\begin{array}{l}\text { BMI } \\
(20.0-24.0)\end{array}$ & 23.0 \\
\hline $\begin{array}{l}\text { Glucose } \\
\text { (negative) }\end{array}$ & negative & $\begin{array}{l}\text { ALT } \\
(4-44 \text { IU) }\end{array}$ & 18 & $\begin{array}{l}\text { Postprandial blood glucose } \\
(<140 \mathrm{mg} / \mathrm{dL})\end{array}$ & 131 \\
\hline \multirow[t]{3}{*}{$\begin{array}{l}\text { Urobilinogen } \\
(+/- \text { or }+)\end{array}$} & $+/-$ & $\begin{array}{l}\text { t- Bilirubin } \\
(<1.2 \mathrm{mg} / \mathrm{dL})\end{array}$ & 0.6 & $\begin{array}{l}\mathrm{HbA1C} \\
(4.6-6.5 \%)\end{array}$ & 6.7 \\
\hline & & $\begin{array}{l}\text { ALP } \\
(104-338 \text { IU/L) }\end{array}$ & 238 & $\begin{array}{l}\text { TG } \\
(45-149 \mathrm{mg} / \mathrm{dL})\end{array}$ & 212 \\
\hline & & $\begin{array}{l}\text { PT } \\
(70-130 \%)\end{array}$ & 81 & $\begin{array}{l}\text { LDL-C } \\
(78-148 \mathrm{mg} / \mathrm{dL})\end{array}$ & 97 \\
\hline \multicolumn{2}{|l|}{$\mathrm{CBC}$} & \multicolumn{2}{|c|}{ Renal function } & \multicolumn{2}{|l|}{ Iron parameters } \\
\hline $\begin{array}{l}\text { WBC } \\
\left(3.8-9.0 \times 10^{3} / \mu \mathrm{L}\right)\end{array}$ & 5.9 & $\begin{array}{l}\text { BUN } \\
(8-20 \mathrm{mg} / \mathrm{dL})\end{array}$ & 8 & $\begin{array}{l}\mathrm{Fe} \\
(44-192 \mu \mathrm{g} / \mathrm{dL})\end{array}$ & 68 \\
\hline $\begin{array}{l}\text { RBC } \\
\left(4.40-5.40 \times 10^{6} / \mu \mathrm{L}\right)\end{array}$ & 4.33 & $\begin{array}{l}\text { Creatinine } \\
(0.60-1.10 \mathrm{mg} / \mathrm{dL})\end{array}$ & 0.84 & $\begin{array}{l}\text { TF-saturation } \\
(40-70 \%)\end{array}$ & 24.5 \\
\hline $\begin{array}{l}\mathrm{Hb} \\
(13.5-17.0 \mathrm{~g} / \mathrm{dL})\end{array}$ & 12.9 & $\begin{array}{l}\text { UA } \\
(4.0-7.0 \mathrm{mg} / \mathrm{dL})\end{array}$ & 5.0 & $\begin{array}{l}\text { Ferritin } \\
(15.0-160 \mathrm{ng} / \mathrm{mL})\end{array}$ & 2,226 \\
\hline $\begin{array}{l}\mathrm{Ht} \\
(40-50 \%)\end{array}$ & 39.7 & $\begin{array}{l}\mathrm{Na} \\
(135-147 \mathrm{mEq} / \mathrm{L})\end{array}$ & 143 & $\begin{array}{l}\text { Hepcidin } 25 \\
(7.8+/-7.0 \mathrm{ng} / \mathrm{mL})\end{array}$ & 73.6 \\
\hline \multirow[t]{2}{*}{$\begin{array}{l}\text { Platelets } \\
\left(15-40 \times 10^{4} / \mu \mathrm{L}\right)\end{array}$} & 17 & $\begin{array}{l}\mathrm{K} \\
(3.3-4.8 \mathrm{mEq} / \mathrm{L})\end{array}$ & 3.5 & & \\
\hline & & $\begin{array}{l}\mathrm{Cl} \\
(98-108 \mathrm{mEq} / \mathrm{L})\end{array}$ & 104 & & \\
\hline
\end{tabular}

Data are presented in order to the test (upper line), normal range (left lower line in parenthesis), and result (right lower line).

Abnormal values are presented in bold numerals.

ALP: alkaline phosphatase, ALT: alanine aminotransferase, BMI: body mass index, BUN: blood urea nitrogen, CBC: complete blood count, Hb: hemoglobin, Ht: hematocrit, LDL-C: low density lipoprotein-cholesterol, PT: prothrombin time, RBC: red blood cell, t-Bilirubin: total-Bilirubin, TF: transferrin, TG: triglyceride, UA: uric acid, WBC: white blood cell

Mild hyperferritinemia and hyperhepcidinemia were associated with mild anemia in the 90-year-old male family member. One abnormal value was $6.7 \% \mathrm{HbA1C}$ : mild glucose intolerance was first found in the member with a $23.0 \mathrm{BMI}$ and $131 \mathrm{mg} / \mathrm{dL}$ postbrandial blood glucose, without glucosuria. Another was hypertriglycemia of unknown origin. 


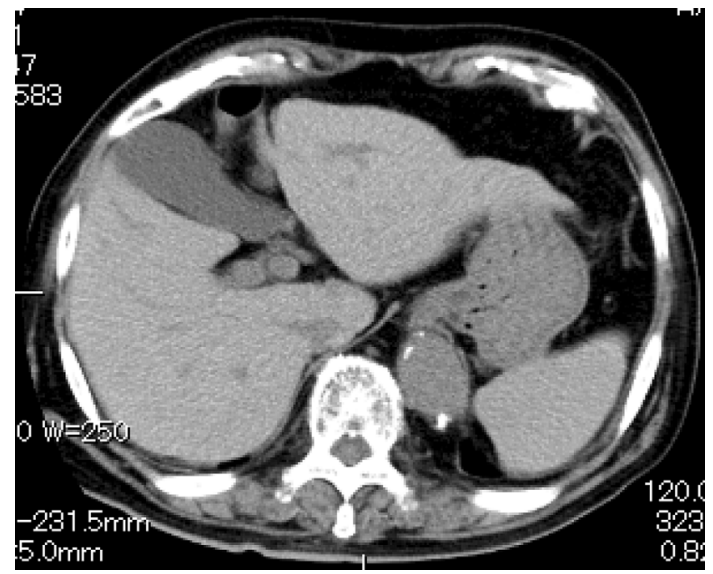

Figure 2. Abdominal CT of the proband's 90-year-old father. The $\mathrm{CT}$ values of the liver and spleen are mildly elevated, suggesting iron overload in the RE system. The other findings are normal, similar to the proband.

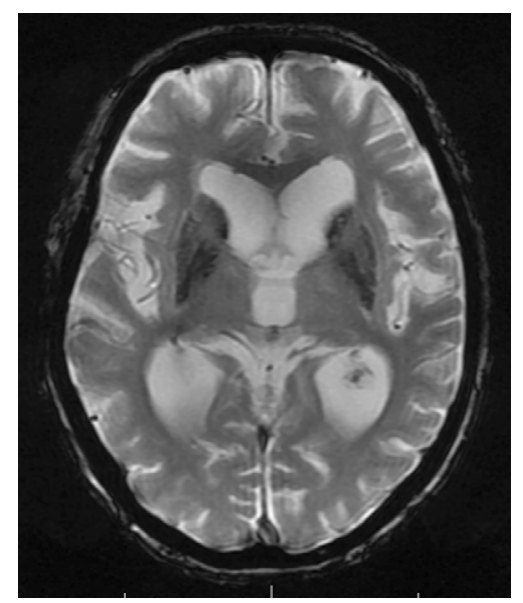

Figure 4. Brain MRI of the proband's 90-year-old father. $\mathbf{T}_{2}$ weighted MRI shows a high signal intensity in the striatum, indicating small metal deposits in his brain. Cortical atrophy appears mild, and right dominant enlargement of the sylvian fissure is observed, suggesting ipsilateral lobe atrophy. Dilatation of the lateral ventricles and the third ventricle was also confirmed on MRI. Based on the comparison of the images to those of a 90-year-old control, these atrophic findings were considered to be aging-related changes.

slightly high, but liver and renal function tests yielded mostly normal results. Abdominal CT showed that the density of the liver and spleen was slightly increased (Fig. 2), indicating mild iron overload of the RE system. Brain CT showed right-dominant atrophy of the temporal lobes and marked atrophy of the hippocampus and amygdala, but otherwise normal findings (Fig. 3). MRI indicated small metal deposits in the striatum (Fig. 4). Cortical atrophy was mild, and right-dominant enlargement of the sylvian fissure suggested ipsilateral lobe atrophy. Dilatation of the lateral ventricles and third ventricle was also confirmed on MRI. These atrophic findings were considered to be aging-related changes based on the comparison of the patient's brain im-

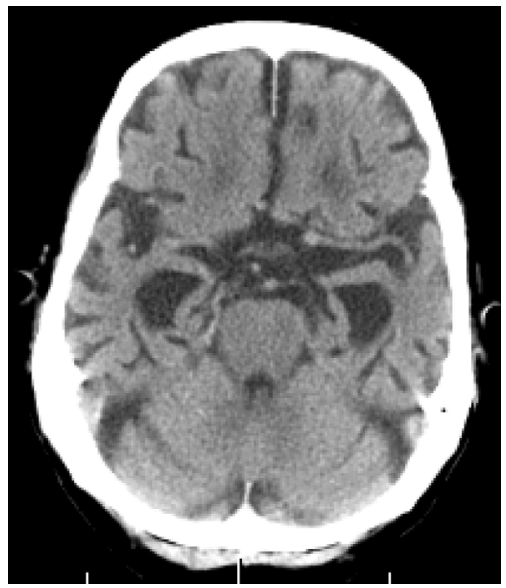

Figure 3. Brain CT of the proband's 90-year-old father. The image shows right dominant atrophy of the temporal lobes and marked atrophy of the hippocampus and amygdala, but an otherwise normal brain.

ages with those of a 90-year-old control.

The iron parameters of the affected members during the 10-year observation period

During the 10-year observation period, the patients did not receive any treatments (i.e., long-term chelation or repeated phlebotomy) for associated asymptomatic iron overload. Both patients were free from any signs of iron overload disease throughout the observation period. Their iron biochemistry parameters remained characteristic of FPD A: mild hyperferritinemia, an appropriate level of circulating hepcidin25, and no damage to the iron-sensitive organs. In comparison to the initial data, the most recent iron parameters and hepatic density based on CT revealed a slight reduction over the 10-year period (Table 3 ). The serum ferritin levels fell from 696 to $479 \mathrm{ng} / \mathrm{mL}$ in the proband and from 2,639 to $2,226 \mathrm{ng} / \mathrm{mL}$ in his father. Their serum levels of hepcidin 25 showed similar changes. As a result, there was a correlation between the serum levels of ferritin and hepcidin25: Y (hepcidin25, ng/mL) $=0.044 \times \mathrm{X}($ ferritin, $\mathrm{ng} / \mathrm{mL})$ $+10.8, \mathrm{R} 2=0.88$. Non-specific mild anemia remained in the father, and similar anemia appeared in the son. Mild glucose intolerance was first noted in the father at 90 years of age.

\section{Discussion}

FPN, with its dual functions of an iron exporter and a hepcidin receptor, plays a central role in post-hepatic iron overload syndrome (9). The interaction between hepcidin and the genetically altered molecules of FPN may determine the clinical features of the patient: phenotype $\mathrm{A}$ is associated with a loss-of-function mutation, while phenotype B is associated with a gain-of-function mutation $(10,11)$. During the 10-year follow-up of our family with FPD A, the serum levels of ferritin declined along with the serum hepacidin 25 concentrations. Liver CT suggested that the iron deposits were reduced in comparison to a previous study. There was 
Table 3. Iron Parameters and Hounsfield Units of the Livers of the Family Members with Ferroportin Disease A.

\begin{tabular}{lcccc}
\hline & \multicolumn{2}{c}{ Proband } & \multicolumn{2}{c}{ Father } \\
\hline Ages when tested & $49 \mathrm{yr}$ & $59 \mathrm{yr}$ & $81 \mathrm{yr}$ & $90 \mathrm{yr}$ \\
Hb $(13.7-16.8 \mathrm{~g} / \mathrm{dL})$ & 14.4 & 13.4 & 13.4 & 12.9 \\
Serum Ferritin $(15.0-160.0 \mathrm{ng} / \mathrm{mL})$ & 696 & 479 & 2,639 & 2,226 \\
Serum Hepcidin25 $(7.8+/-7.0 \mathrm{ng} / \mathrm{mL})$ & 42.5 & 37.5 & 155 & 73.6 \\
Hepatic CT $(50-65 \mathrm{HU})$ & 74 & 70 & no test & 78 \\
\hline
\end{tabular}

CT: computed tomography, Hb: hemoglobin, HU: Hounsfield units

Serum hepcidin 25 levels were appropriately high parallel to their hyperferritinemias. In addition, these iron parameters reduced slightly in the second tests. Note the correlation between serum levels of ferritin and hepcidin25: Y (hepcidin25) $=0.044 \times \mathrm{X}$ (ferritin) $+10.8, \mathrm{R} 2=0.88$. Hepatic CT units were moderately high in both members, suggesting mild iron overload in their livers. Based on these data, their iron overload conditions were improved over the 10-year observation period. However, mild anemia remained in the father, and appeared in the proband.

These unexpected results on the natural history of a genetic iron overload syndrome may have been mainly due to a habitual change to a low iron diet after being diagnosed.

Table 4. Japanese Patients with Hereditary Iron Overload Syndromes and Their Characteristics.

\begin{tabular}{|c|c|c|c|c|}
\hline Category & Disease Entities $\#$ a & Major Phenotype ${ }^{\# b}$ & Subtype ${ }^{\# b}$ & Remarks \\
\hline \multirow[t]{2}{*}{ Pre-hepatic } & $\begin{array}{l}\text { Iron loading } \\
\text { anemias }(0)\end{array}$ & MDS & $\begin{array}{l}\text { Hereditary hemolytic anemia } \\
\text { and hereditary sideroblastic } \\
\text { anemia }\end{array}$ & $\begin{array}{l}\text { Triad of anemia, iron } \\
\text { overload, and } \\
\text { hypohepcidinemia }\end{array}$ \\
\hline & $\begin{array}{l}\text { Aceruloplasminemia } \\
\text { (a major genotype) }\end{array}$ & $\begin{array}{l}\text { DM/Brain disease } \\
(59 \mathrm{yr}, \mathrm{F}, 885 \mathrm{ng} / \mathrm{mL}, 32 \mathrm{IU} / \mathrm{dL} \text {, } \\
10.3 \mathrm{ng} / \mathrm{mL})^{9)}\end{array}$ & $\begin{array}{l}\text { DM alone } \\
(44 \mathrm{yr}, \mathrm{M}, 961 \mathrm{ng} / \mathrm{mL} \\
42 \mathrm{IU} / \mathrm{dL}, 2.7 \mathrm{ng} / \mathrm{mL})^{9)}\end{array}$ & $\begin{array}{l}\text { Low levels of } \mathrm{Hb} \text {, transferrin } \\
\text { saturation, and hepcidin } 25 \\
\text { No liver disease }\end{array}$ \\
\hline \multirow{4}{*}{ Hepatic } & $\begin{array}{l}\text { HFE, Y231del, homo. } \\
\text { (1) }\end{array}$ & $\begin{array}{l}\text { Classical HH with the triad } \\
(43 \mathrm{yr}, \mathrm{M}, 1,698 \mathrm{ng} / \mathrm{mL} \text {, } \\
52 \mathrm{IU} / \mathrm{dL}, \mathrm{BDL})^{21)}\end{array}$ & & $\begin{array}{l}\text { The gene of Huh- } 7 \text { derived } \\
\text { from Japanese hepatoma }\end{array}$ \\
\hline & $\begin{array}{l}\text { TFR2 } \\
\text { (a major genotype) }\end{array}$ & $\begin{array}{l}\text { Classical HH with the triad, } \\
\text { the most severe case } \\
(40 \mathrm{yr}, \mathrm{M}, 10,191 \mathrm{ng} / \mathrm{mL} \text {, } \\
48 \mathrm{IU} / \mathrm{dL}, 12 \mathrm{ng} / \mathrm{mJ})^{9)}\end{array}$ & $\begin{array}{l}\text { Classical } \mathrm{HH} \text { with the triad, } \\
\text { the most mild case } \\
(49 \mathrm{yr}, \mathrm{M}, 1,057 \mathrm{ng} / \mathrm{mL} \text {, } \\
34 \mathrm{IU} / \mathrm{dL}, 2.8 \mathrm{ng} / \mathrm{mL})^{9)}\end{array}$ & A wide range of iron loading \\
\hline & $\begin{array}{l}\text { HJV } \\
\text { (a major genotype) }\end{array}$ & $\begin{array}{l}\text { Juvenile } \mathrm{HH} \text { with the triad plus } \\
\text { cardiac disease and } \\
\text { hypogonadism } \\
(13 \mathrm{yr}, \mathrm{M}, 16,000 \mathrm{ng} / \mathrm{mL} \text {, } \\
122 \mathrm{IU} / \mathrm{dL})^{9)}\end{array}$ & $\begin{array}{l}\text { Classical HH with the triad } \\
(48 \mathrm{yr}, \mathrm{M}, 6,115 \mathrm{ng} / \mathrm{mL} \text {, } \\
109 \mathrm{IU} / \mathrm{dL}, \mathrm{BDL})^{9)}\end{array}$ & $\begin{array}{l}\text { Split phenotyping maybe due } \\
\text { to mutant and diet. }\end{array}$ \\
\hline & $\begin{array}{l}\text { HAMP } \\
\text { (1) }\end{array}$ & $\begin{array}{l}\text { Juvenile } \mathrm{HH} \text { with the triad plus } \\
\text { cardiac disease and } \\
\text { hypogonadism } \\
(26 \mathrm{yr}, \mathrm{M}, 3,000 \mathrm{ng} / \mathrm{mL} \\
104 \mathrm{IU} / \mathrm{dL}, \mathrm{BDL})^{9)}\end{array}$ & & $\begin{array}{l}\text { No hepcidin molecules } \\
\text { detected in the Japanese } \\
\text { patient }\end{array}$ \\
\hline Post-hepatic & $\begin{array}{l}\text { FPD, SCLAOA1, } \\
\text { hetero. } \\
\text { Type A (2) and B (2) }\end{array}$ & $\begin{array}{l}\text { Loss-of-function Type A } \\
\text { (49 yr, M, } 696 \mathrm{ng} / \mathrm{mL} \text {, } \\
24 \mathrm{IU} / \mathrm{dL}, 42.5 \mathrm{ng} / \mathrm{mL})^{9)}\end{array}$ & $\begin{array}{l}\text { Gain-of-function Type B with } \\
\text { DM, CAH, and pigmentation } \\
(66 \mathrm{yr}, \mathrm{M}, 7,980 \mathrm{ng} / \mathrm{mL} \text {, } \\
\left.44 \mathrm{IU} / \mathrm{dL}, 157 \mathrm{ng} / \mathrm{mL})^{9}\right)\end{array}$ & $\begin{array}{l}\text { Activated RE cells } \\
\text { Mutant-dependent phenotypes }\end{array}$ \\
\hline
\end{tabular}

MDS: myelodysplastic syndrome, HH: hereditary hemochromatosis, DM: diabetes mellitus, RE: reticuloendothelial, HH with the triad: hereditary hemochromatosis with DM, cirrhosis and pigmentation, $\mathrm{CAH}$ : chronic active hepatitis

\#a: The number of Japanese patients reported and comments are cited within the first parentheses.

\#b: The clinical and biochemical data of a representative patient with the phenotype are presented in order of the age (yr), sex (M: male; F: female), serum ferritin (ng/dL), alanine aminotransferase: ALT (IU: international units) and hepcidin25 (ng/mL) in parentheses. Some patients lacked the most recent figures for hepci$\operatorname{din} 25$.

Ref. \#: Reference No. cited in the test.

Exceptionally, there were no data available for Japanese patients with iron loading anemias in our liver disease laboratory.

Iron-induced organ damage shows a wide range, from the 5 diseases of juvenile HH to asymptomatic FPD A. Anemia in iron loading anemia is partially due to genetically impaired erythropoiesis caused by toxic iron in the bone marrow, while mild anemia and intolerance to blood donation and phlebotomy in FPD A may not be due to iron toxicity, but the disturbance of iron transport in the bone marrow. 
no evidence of major organ damage in the affected members with the exception of gait disturbance, cognitive failure, and mild glucose intolerance in the proband's elderly father. His age-matched brain images should be differentiated from neurodegeneration due to the accumulation of iron in the brain (18). DM, which was noticed at 90 years of age, might have been iron-induced disease; however, it did not require medical treatment (19).

As summarized in Table 4, there have been few reported cases of Japanese patients with genetic iron overload syndromes and most such patients show non-HFE genotypes $(9,20,21)$. These patients show a wide range of the clinical features from 5 types of organ damage associated with DM, cirrhosis, pigmentation, cardiac disease, and hypogonadism in juvenile $\mathrm{HH}$ to no major organ damage in FPD A. The combination of organs affected differs depending on the responsible gene, disease-causing mutant, and agedependent stage at the time of the diagnosis. The serum ferritin level is a reliable marker of the body's iron store, but it is markedly affected by age, sex, liver disease activity, and the iron regulatory hormone hepcidin 25 . Thus, the prognosis of patients with iron overload conditions should be assessed based on the genotype and its subtype $(2,3)$. HH, when not diagnosed, may progress from cirrhosis to hepatoma; thus, patients with traits associated with $\mathrm{HH}$ should be carefully examined and phlebotomy should be performed to treat $\mathrm{HH}$ when it is diagnosed. Since patients with aceruloplasminemia (ACP) or FPD associated with mild anemia are intolerant to phlebotomy $(11,22)$, it is especially important to screen for individuals with these disease traits at the early stage of iron overloading. The determination of serum ferritin levels in adolescents is the first test to screen for patients with iron overload (16). In the case of ACP, the second test is to measure the circulating ceruloplasmin (CP) level, followed by the final diagnostic test for the $C P$ gene (23). In the case of FPD, the second test is for the circulating hepcidin 25 . When the level is appropriately high, an SLC4OA1 gene analysis should be performed, followed by phenotyping, to determine whether the phenotype is A or B (11). The clinical features of our family members, who remained free from major organ damage during the 10-year follow-up study period, strongly supported the presence of a subtype of type A. When the findings are questionable, a functional analysis of the mutant gene (24) and the prediction of the protein function using amino acid substitution (25) are available for the differential diagnosis. Considering that the anemia of the family members did not improve, even after the improvement of the iron state, erythropoiesis might have been impaired by the restricted utilization of iron, and not by toxic iron in the bone marrow. The anemia of the patients was asymptomatic and did not reduce their activities of daily living.

The natural improvement of the iron states of patients with genetic iron overload syndrome may be exceptional $(2,3)$. The results of the follow-up study may suggest the mildness of the FPD A in the present case was due to a loss-of-function mutation, R489S $(1,467 \mathrm{~A}>\mathrm{C} / \mathrm{wt})$, in the SLC40A1 gene. Another mutation, R489K $(1,466 \mathrm{G}>\mathrm{A} / \mathrm{wt})$ at the same locus as our family, was identified in a large family with FPD A (26). The habitual diet of our family members might have been an additional factor. The proband, a retired paramedic of a general hospital, could not tolerate phlebotomy or an oral iron chelator; thus, the family members had changed to a low-iron diet after the diagnosis of iron disease. The body's iron balance may have been positive for the first 49 years of the proband's life and negative in the most recent 10 years, while it might have been positive for the first 81 years of his father's life and negative in the most recent 10 years; the longer period of the positive phase might have resulted in a heavier iron overload in the father. Further cases should be accumulated to confirm the importance of the genetic diagnosis and phenotyping in FPD, and to determine whether some patients with the FPD A who have mild anemia and intolerance to phlebotomy can avoid intensive treatment (11).

In conclusion, the minimal damage to the iron-sensitive organs in our family members suggests that some cases of FPD A may be benign rather than pathological.

\section{The authors state that they have no Conflict of Interest (COI).}

\section{References}

1. Hayashi H, Wakusawa S, Motonishi S, et al. Genetic background of primary iron overload syndromes in Japan. Intern Med 45: 1107-1111, 2006.

2. Pietrangelo A. Genetics, genetic testing, and management of hemochromatosis: 15 years since hepcidin. Gastroenterology 149: 1240-1251, 2015.

3. Kawabata H. The mechanisms of systemic iron homeostasis and etiology, diagnosis, and treatment of hereditary hemochromatosis. Int J Hematology 107: 31-43, 2018.

4. Montosi G, Donovan A, Totaro A, et al. Autosomal-dominant hemochromatosis is associated with a mutation in the FPN (SLC11A3) gene. J Clin Invest 108: 619-623, 2001.

5. Njajou OT, Vaessen $\mathrm{N}$, Joosse $\mathrm{M}$, et al. A mutation in SLC11A3 is associated with autosomal dominant hemochromatosis. Nat Genet 28: 213-214, 2001.

6. Ganz T. Hepcidin, a key regulator of iron metabolism and mediator of anemia of inflammation. Blood 102: 783-788, 2003.

7. Nemeth E, Tuttle MS, Powelson J, et al. Hepcidin regulates cellular iron efflux by binding to FPN and inducing its internalization. Science 306: 2090-2093, 2004.

8. Drakesmith H, Schimanski LM, Ormerod E, at al. Resistance to hepcidin is conferred by hemochromatosis-associated mutations of ferroportin. Blood 106: 1092-1097, 2005.

9. Hattori A, Miyajima H, Tomosugi N, et al. Clinicopathological study of Japanese patients with genetic iron overload syndromes. Pathol Int 62: 612-618, 2012.

10. Letocart E, Le Gac G, Majore $S$, et al. A novel missense mutation in SLC40A1 results in resistance to hepcidin and confirms the existence of two ferroportin-associated iron overload diseases. $\mathrm{Br} \mathrm{J}$ Haematol 147: 379-385, 2009.

11. Pietrangelo A. Ferroportin disease: pathogenesis, diagnosis and treatment.. Haematologica 102: 1972-1984, 2017.

12. Liu W, Shimomura S, Imanishi $H$, et al. Hemochromatosis with mutation of the ferroportin 1 (IREG1) gene. Intern Med 44: 285- 
289, 2005.

13. Yamashita T, Morotomi N, Sohda T, et al. A male patient with ferroportin disease $\mathrm{B}$ and a female patient with iron overload similar to ferroportin disease B. Clin J Gastroenterol 7: 260-264, 2014.

14. Koyama C, Wakusawa S, Hayashi $\mathrm{H}$, et al. A Japanese family with FPD caused by a novel mutation of $S L C 4 O A 1$ gene: hyperferritinemia associated with a relatively low transferring saturation of iron. Intern Med 44: 990-993, 2005.

15. Murao N, Ishigai $M$, Yasuno $H$, Shimonaka Y, Aso Y. Simple and sensitive quantification of bioactive peptides in biological matrices using liquid chromatography/selected reaction monitoring mass spectrometry coupled with trichloroacetic acid clean-up. Rapid Commun Mass Spectrom 21: 4033-4038, 2007.

16. Kaneko Y, Miyajima H, Piperno A, et al. Measurement of serum hepcidin-25 levels as a potential test for diagnosing hemochromatosis and related disorders. J Gastroenterol 45: 1163-1171, 2010.

17. Unal S, Piperno A, Gumruk F. Iron chelation with deferasirox in a patient with de-novo ferroportin mutation. J Trace Elem Med Biol 30: 1-3, 2015.

18. McNeill A, Birchall D, Hayflick SJ, et al. T2* and FSE MRI distinguishes four subtypes of neurodegeneration with brain iron accumulation. Neurology 70: 1614-1619, 2008.

19. Ito $\mathrm{H}$. Evidences from J-EDIT for diabetes mellitus in the elderly. Nihon Rinsho 71: 1923-1931, 2013 (in Japanese, Abstract in English).

20. Sohda T, Okubo R, Kamimura S, Ohkawara T. Hemochromatosis with HFE gene mutation in a Japanese patient. Am J Gastroenterol
96: $2487-2488,2001$.

21. Takano A, Niimi H, Atarashi Y, et al. A novel Y231del mutation of HFE in hereditary haemochromatosis provides in vivo evidence that the Huh-7 is a human haemochromatotic cell line. Liver Int 31: 1593-1597, 2011.

22. Yoshida K, Furihata $K$, Takeda $S$, et al. A mutation in the ceruloplasmin gene is associated with systemic hemosiderosis in humans. Nat Genet 9: 267-272, 1995.

23. McNeill A, Pandolfo M, Kuhn J, Shang H, Miyajima H. The neurological presentation of ceruloplasmin gene mutations. Eur Neurol 60: 200-205, 2008.

24. Le Lan C, Mosser A, Ropert M, et al. Sex and acquired cofactors determine phenotypes of ferroportin disease. Gastroenterology 140: 1199-1207, 2011.

25. Mayr R, Janecke AR, Schranz M, et al. Ferroportin disease: a systematic meta-analysis of clinical and molecular findings. J Hepatol 53: 941-949, 2010

26. Griffiths WJ, Mayr R, McFarlane I, et al. Clinical presentation and molecular pathophysiology of autosomal dominant hemochromatosis caused by a novel ferroportin mutation. Hepatology 51: 788795, 2010.

The Internal Medicine is an Open Access article distributed under the Creative Commons Attribution-NonCommercial-NoDerivatives 4.0 International License. To view the details of this license, please visit (https://creativecommons.org/licenses/ by-nc-nd/4.0/).

(C) 2018 The Japanese Society of Internal Medicine Intern Med 57: 2865-2871, 2018 